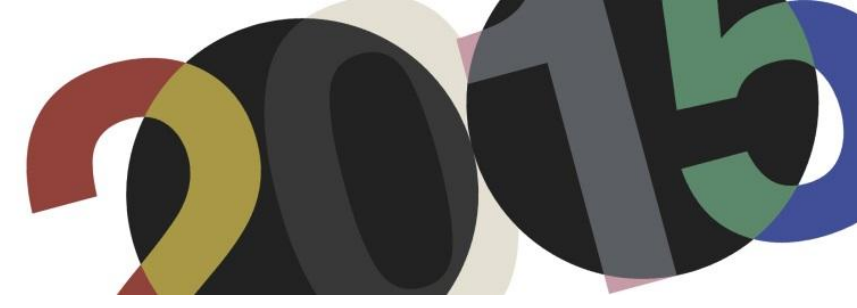

DOI: http://dx.doi.org/10.4995/LC2015.2015.893

\title{
Experimenting with prototypes: architectural research in Sweden after Le Corbusier's projects
}

\section{Campo-Ruiz}

\author{
Escuela Técnica Superior de Arquitectura de Madrid, Universidad Politécnica de Madrid
}

\begin{abstract}
Le Corbusier's architectural production throughout the twentieth century served as a reference for subsequent developments in architecture and urban planning in Sweden. Some of the buildings and urban plans subsequently developed in Sweden and influenced by Le Corbusier's ideas and projects also impacted on the international architectural scene. This research analyses how the study of Le Corbusier's works affected projects in Sweden from the 1920s to the 1970s and how they also became an international standard. Le Corbusier's works provided a kind of prototype, with which Swedish architects experimented in alternative ways. During the 1920s, Le Corbusier's Pavilion de l'Esprit Nouveau and the Stuttgart Weissenhofsiedlung impressed influential Swedish architect, including Uno Åhrén, Gunnar Asplund and Sven Markelius, who later became proponents of modernism in Sweden. The 1930 Stockholm Exhibition marked a breakthrough for functionalism in Sweden. After 1930, urban plans for Stockholm and its suburbs reflected some of Le Corbusier's ideas, such as the urban plan by Sven Markelius, and Vällingby's town centre by Leif Reinius and Sven Backström. After 1950, Léonie Geisendorf, Ralph Erskine, Sigurd Lewerentz and Peter Celsing placed considerable emphasis on rough texture in poured concrete. Lewerentz, who admired the works of Le Corbusier, designed the churches of Markuskyrkan in 1956 and St Peter's in Klippan in 1966, with a wider international impact. Reyner Banham included several works by Le Corbusier and also Markuskyrkan Church by Lewerentz in his book The New Brutalism: Ethic or Aesthetic? in 1966.
\end{abstract}

Keywords: Sweden, twentieth-century architecture, urban planning, prototype, architectural experiment, functionalism.

\section{Introduction}

"If you are going to see beautiful churches in Europe, there are three you should not miss: St Peter's Basilica in Rome, Nôtre Dame in Paris and Västerort Church in Vällingby!" ${ }^{1}$ A statement by Le Corbusier after his 1958 visit to this little church in Sweden on the outskirts of Stockholm, designed by Carl Nyrén and Bertil Engstrand and completed two years before. Le Corbusier praised this building, while some architects in Sweden also paid close attention to Le Corbusier's projects.

Le Corbusier's architectural production throughout the twentieth century served as a reference for subsequent developments in architecture and urban planning in Sweden. Some of the buildings and urban plans developed in Sweden and influenced by Le Corbusier's ideas and projects also impacted on the international architectural scene. This research analyses how the study of Le Corbusier's works affected projects in Sweden from the 1920s to the 1970s and how they turn became a benchmark for the international architectural arena. Le Corbusier's works became a kind of prototype, with which Swedish architects experimented in alternative ways.

\footnotetext{
${ }^{1}$ Brandão Jönsson, Henrik: Fantasiön: ett reportage från Brasiliens hjärta. Stockholm: Atlas, 2010. p. 273.
} 
Many forms proposed by Le Corbusier were adopted in Sweden and adapted to the emerging needs of a society that increasingly demanded equality at all levels, as reflected in the Social Democratic government that came into power in 1932, and embraced environmental design as a means to achieve higher living standards. Current socially inclusive designs may find a resource in these Swedish experiments.

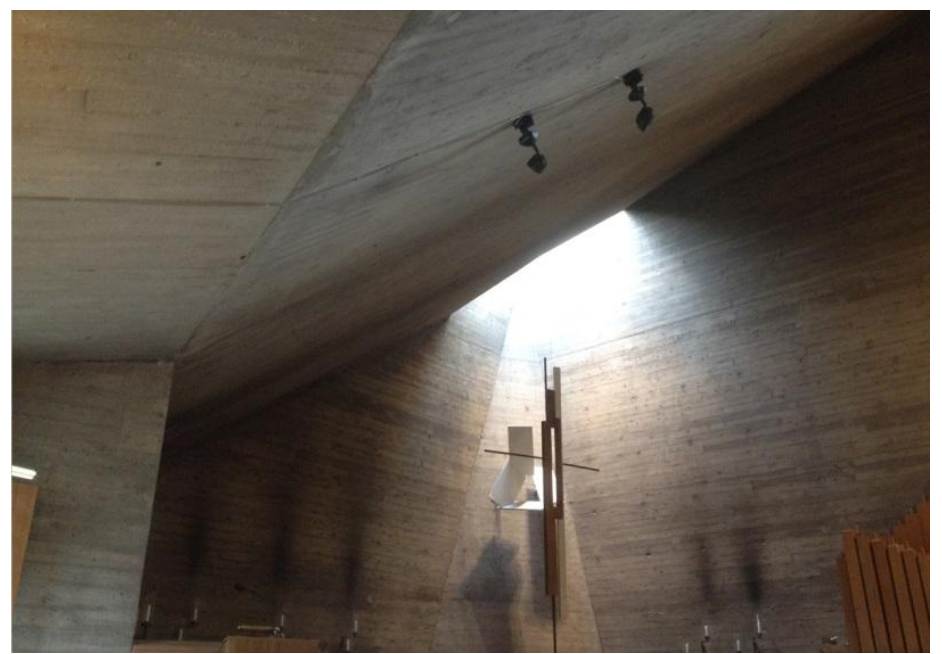

1. Interior of Västerort Church in Vällingby designed by Carl Nyrén and Bertil Engstrand, 1956.

\section{From 1920s to the mid-1930s. L' Esprit Nouveau as a springboard for experimentation at the Stockholm Exhibition}

In 1930, the Swedish Society for Crafts and Design (Svenska Sjöjdföreningen) organised the Stockholm Exhibition of applied art, industrial design, handicrafts, domestic craft, dwellings and other objects. The art historian Gregor Paulsson (1889-1977), Director of this society since 1924, and Gunnar Asplund (1885-1940), Chief Architect, started working on the new exhibition master plans and major buildings in 1927. Asplund began by drafting sketches of the buildings following Classical aesthetics. ${ }^{2}$

However, Asplund and Paulsson's 1928 trip to Brno and Stuttgart to visit Le Corbusier's work may have played a key role in Asplund's evolution towards functionalism, reflected in his drawings for the exhibition. ${ }^{3}$ In 1919 , Paulsson had published a polemic pamphlet, Better Things for Everyday Life, in which he advocated that industrial and rational design should benefit social progress. ${ }^{4}$ Indeed, in many of Le Corbusier's modernist forms, Paulsson now saw an opportunity to render architecture and design more accessible to all.

Additionally, a number of well-known Swedish architects who contributed to the Stockholm Exhibition were aware of some Le Corbusier's works: Uno Åhrén (1897-1977), Sven Markelius (1889-1972), Osvald Almqvist (1884-1950) and Sigurd Lewerentz (1885-1975), among others. Lewerentz designed the exhibition's logo, the posters, the Green Point café, the advertising mast, several stands, furniture and a bus for General Motors.

\footnotetext{
${ }^{2}$ Rudberg, Eva: “The Stockholm Exhibition 1930”. In Manuel López-Peláez, José; Fernández Elorza, Héctor; Rudberg, Eva (Ed.): Exposición Universal de Estocolmo 1930. Madrid: Editorial Rueda, 2004. p. 27.

${ }^{3}$ Rudberg, Eva: “The Stockholm Exhibition 1930”. In Manuel López-Peláez, José; Fernández Elorza, Héctor; Rudberg, Eva (Ed.): Exposición Universal de Estocolmo 1930. Madrid: Editorial Rueda, 2004. pp. 25-39. Also Hakon Ahlberg and Uno Åhrén.

${ }^{4}$ Kåberg, Helena: “An Introduction to Gregor Paulsson's Better Things for Everyday Life.” In Creagh, Lucy; Kåberg, Helena; Miller Lane, Barbara (Ed.): Modern Swedish Design. New York: The Museum of Modern Art, 2008. pp. 59-71.
} 
Osvald Almqvist focused on the standardisation of kitchens and contributed to the housing section. He had already developed a pioneering work on Taylorist studies in kitchen use as early as $1920 .^{5}$

Uno Åhrén visited Le Corbusier house at the Weissenhofsiedlung Exhibition. ${ }^{6}$ Le Corbusier and Pierre Jeanneret had built there a Citrohan house and an adjacent double house, where they tested solutions for minimal housing conditions. ${ }^{7}$ Supporting Stuttgart's project, Le Corbusier launched one of his bluntest manifestos in which he formulated the Five Points of a New Architecture. The success of the Stuttgart Exhibition led to the creation in 1928 of the Congrès Internationaux d'Architecture Moderne (CIAM) at La Sarraz Castle. Le Corbusier played a key role in the first meeting and his ideas strongly influenced subsequent congresses in Frankfurt, Brussels, Athens and Paris dedicated to minimal housing conditions and the functional city. ${ }^{8}$

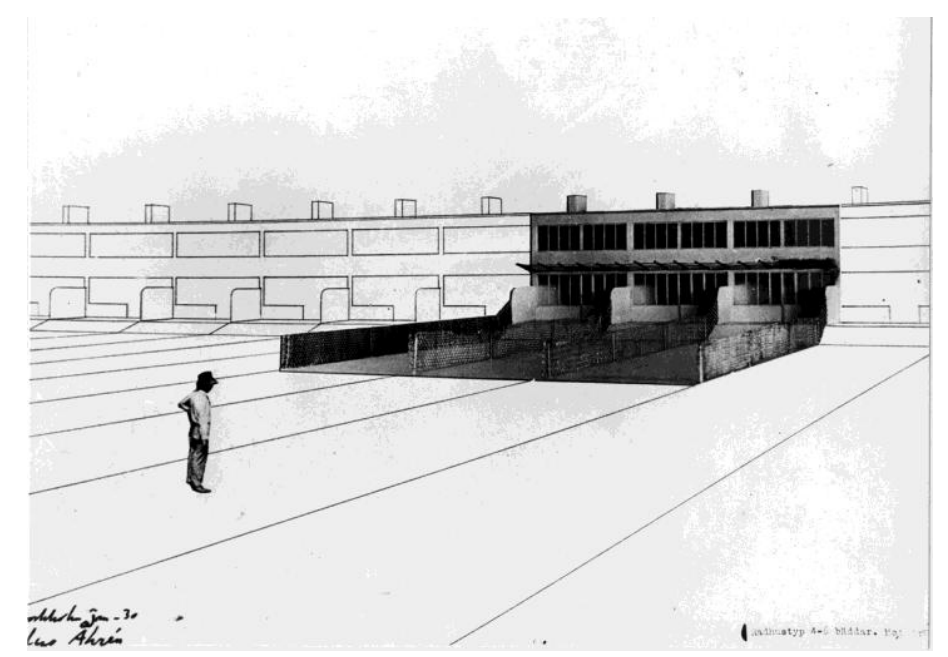

2. One of Åhrén's proposal of dwellings for the 1930 Stockholm Exhibition, a project for a single house, photomontage.

At the Stockholm Exhibition, Åhrén revealed his research on functional dwellings for the housing section, the Hall of Apartments, a terrace house, a one-family house, furniture and a small pavilion. Despite the palpable similarities between Åhrén's work and some of Le Corbusier's ideas, Åhrén critiqued Le Corbusier's contributions at the Weissenhofsiedlung for his preference of the play of formal over functional qualities and considered that the whole exhibition had failed in this aspect, with the exception of Oud and Gropius. ${ }^{9}$ Although Åhrén had previously defended Le Corbusier's L'Esprit Nouveau pavilion and emphasised the functions of the designs, he found Le Corbusier's project for Stuttgart too luxurious. ${ }^{10}$ Curiously enough, Åhrén used similar panoramic windows and white-washed surfaces to those of Le Corbusier's project at the Weissenhofsiedlung to materialise some of his principles and opposition to Le Corbusier's luxuries. Åhrén challenged personal

\footnotetext{
${ }^{5}$ Gasterland-Gustafsson, Grechen: Design for Living: German and Swedish Design in the Early Twentieth Century. Doctoral Thesis. Supervisor: Jochen Schulte-Sasse. University of Minnesota, 2008. p.163.

${ }^{6}$ Mattson, Helena; Wallenstein, Sven-Olov: Swedish Modernism: Architecture, Consumption and the Welfare State. London: Black Dog Publishing, 2010. p. 18.

${ }^{7}$ Cohen, Jean-Louis: Le Corbusier, 1887-1965. Köln: Taschen, 2004. p.35.

${ }^{8}$ Cohen, Jean-Louis: Le Corbusier, 1887-1965. Köln: Taschen, 2004. p. 36.

${ }^{9}$ Gasterland-Gustafsson, Grechen: Design for Living: German and Swedish Design in the Early Twentieth Century. Doctoral Thesis. Supervisor: Jochen Schulte-Sasse. University of Minnesota, 2008. p.163.

${ }^{10}$ Eriksson, Eva: "Rationalism and Classicism 1915-30." In Cladenby, Claes; Lindvall, Jöran; Wang, Wilfried (Ed.): Sweden 20th Century Architecture. Munich-New York: Prestel, 1998. p. 73.
} 
expression in favour of rational decisions for a collective interest in numerous controversial articles. ${ }^{11}$ Åhrén claimed that "the future or decline of Western culture depends on whether it is possible to be modern in a deeply human and fruitful sense" ${ }^{\text {"12 }}$. Åhrén posited that building costs challenged affordable housing with minimum quality standards, revealing the political implication at stake. ${ }^{13}$ Two years after the Stockholm Exhibition, Åhrén became a member of the CIAM and joined its media department, where he concentrated on the political and propagandistic effects of architectural work. ${ }^{14}$

For the Stockholm Exhibition, Sven Markelius designed the hospital section, a flat, a one-family house and furniture. As a young student, Markelius had travelled to Germany where he met Gropius, visited his Siedlung Dessau-Törten project, followed by the Weissenhof Siedlung and, in France, Ville Savoye, still under construction. ${ }^{15}$ In 1929, Markelius had recently become a member of the CIAM, taking part in meetings in Frankfurt and Berlin in in 1929 and 1931, respectively.

The Stockholm Exhibition was constructed from late 1929 to early 1930. Most of the buildings had timber frames covered by asbestos-cement sheets, although a few buildings were built with steel frames. The exhibition attracted 4 million visitors and a broad analysis from international and domestic media. ${ }^{16}$ According to Sigfried Gideon, International Secretary of the CIAM, "There's been no exhibition to rival this one for overall effect?"17

One year after the exhibition, several architects published the manifesto acceptera, which Lorenzo Capbianco believes to have been influenced by Le Corbusier. ${ }^{18}$ Authored by Åhrén, Paulsson, Asplund, Markelius, Walter Gahn (1890-1985) and Eskil Sundahl (1890-1974), the manifesto aimed to break with the architectural thinking that had dominated Swedish discourse until then, criticising historical eclecticism and advocating unadorned surfaces. ${ }^{19}$

\footnotetext{
${ }^{11}$ Creagh, Lucy: "An Introduction to acceptera". En Creagh, Lucy; Kåberg, Helena; Miller Lane, Barbara (Ed.): Modern Swedish Design. New York: The Museum of Modern Art, 2008. p. 131.

${ }^{12}$ Eriksson, Eva: "Rationalism and Classicism 1915-30." In Cladenby, Claes; Lindvall, Jöran; Wang, Wilfried (Ed.): Sweden 20th Century Architecture. Munich-New York: Prestel, 1998. p. 74.

${ }^{13}$ Rudberg, Eva: “Early Functionalism 1930-40." En Cladenby, Claes; Lindvall, Jöran; Wang, Wilfried (Ed.): Sweden 20th Century Architecture. Munich-New York: Prestel, 1998. p. 91.

${ }^{14}$ Mattson, Helena; Wallenstein, Sven-Olov: Swedish Modernism: Architecture, Consumption and the Welfare Stat. London: Black Dog Publishing, 2010. p. 18.

${ }^{15}$ Rudberg, Eva: “The Stockholm Exhibition 1930”. In Manuel López-Peláez, José; Fernández Elorza, Héctor; Rudberg, Eva (Ed.): Exposición Universal de Estocolmo 1930. Madrid: Editorial Rueda, 2004. p. 45.

${ }^{16}$ Rudberg, Eva: “The Stockholm Exhibition 1930”. In Manuel López-Peláez, José; Fernández Elorza, Héctor; Rudberg, Eva (Ed.): Exposición Universal de Estocolmo 1930. Madrid: Editorial Rueda, 2004. p. 26.

${ }^{17}$ Rudberg, Eva: “The Stockholm Exhibition 1930”. In Manuel López-Peláez, José; Fernández Elorza, Héctor; Rudberg, Eva (Ed.): Exposición Universal de Estocolmo 1930. Madrid: Editorial Rueda, 2004. p. 25

${ }^{18}$ Rudberg, Eva: “The Stockholm Exhibition 1930”. In Manuel López-Peláez, José; Fernández Elorza, Héctor; Rudberg, Eva (Ed.): Exposición Universal de Estocolmo 1930. Madrid: Editorial Rueda, 2004. p. 15.

${ }^{19}$ Creagh, Lucy: "An Introduction to acceptera". En Creagh, Lucy; Kåberg, Helena; Miller Lane, Barbara (Ed.): Modern Swedish Design. New York: The Museum of Modern Art, 2008. p. 127.
} 


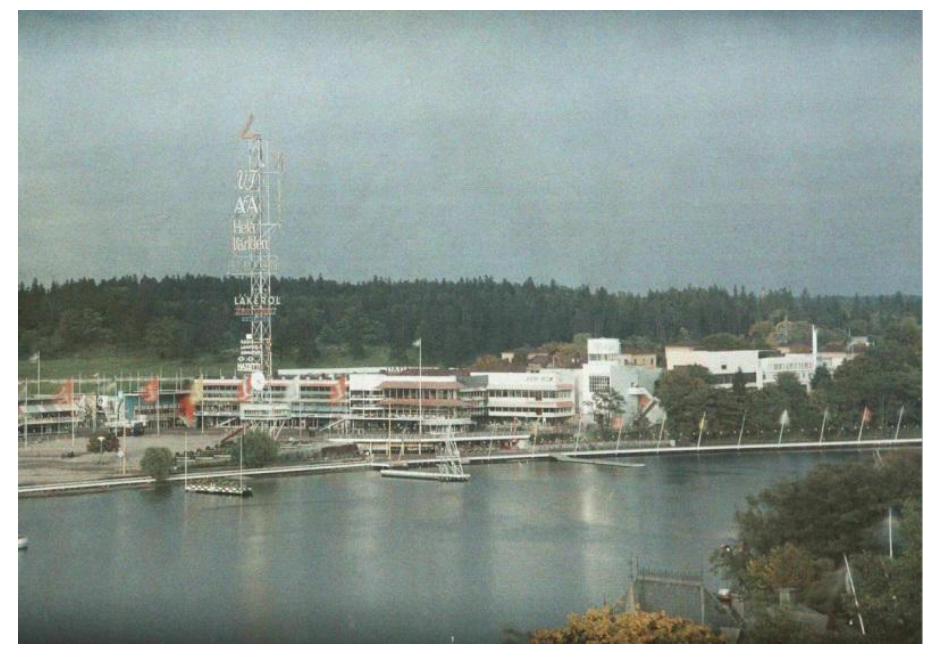

3. The Stockholm Exhibition of 1930, director Gregor Paulsson and Chief architect, Gunnar Asplund.

The works developed for the Stockholm Exhibition uncovered an adaptation of functionalism in Sweden that triggered further international interest. Henry-Russell Hitchcock and Philip Johnson showed the pavilions for the Stockholm Exhibition in the International Modern Architecture Exhibition at New York's MOMA in $1932 .{ }^{20}$ Hitchcock and Johnson subsequently published the celebrated book The International Style: Architecture since 1922, featuring Asplund's works at the Stockholm Exhibition, with a lakeside axonometric of the site and a photograph of the area between the Mass-produced Furniture and The Noble Metals pavilions. ${ }^{21}$ This book also featured the Flamman Theatre Auditorium in Stockholm by Uno Åhrén.

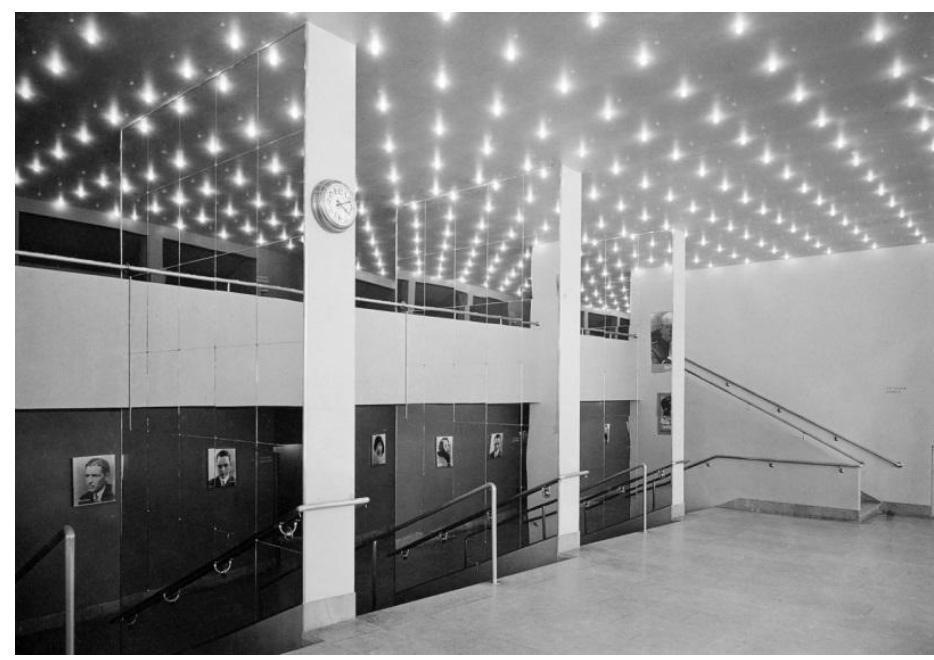

4. Åhrén's Flamman Theatre, 1929-1930.

Asplund was the focus of heavy criticism from Hakon Ahlberg, an influential architect in Sweden at that time: "it was Asplund, but it was also somebody else, somebody stronger who was behind his work. Aladdin had

\footnotetext{
${ }^{20}$ López-Peláez, José Manuel: “Asplund's Maturity”. En López-Peláez, José Manuel; Fernández Elorza, Héctor; Rudberg, Eva (Comp.): Exposición Universal de Estocolmo 1930. Madrid: Editorial Rueda, 2004. p.41.

${ }^{21}$ López-Peláez, José Manuel: “Asplund's Maturity”. En López-Peláez, José Manuel; Fernández Elorza, Héctor; Rudberg, Eva (Comp.): Exposición Universal de Estocolmo 1930. Madrid: Editorial Rueda, 2004. p.41.
} 
rubbed his lamp and the castle in the air was there, made of shiny material. However, the genie of the lamp was Le Corbusier: without his help, this work would not have existed"22.

However, in the words of Kenneth Frampton, "in no way can we regard the Stockholm Exhibition as being a Neo-Corbusian from a formal point of view, since, apart from the steel stanchions, the ubiquitous strip window and the general use of flush planar surfaces, none of the Corbusian Five Points of a New Architecture are strictly in evidence at Stockholm"23. Instead, Frampton claims that the exhibition was under the influence of the Russian Constructivists.

In fact, many of the works shown at the Stockholm Exhibition embraced some of Le Corbusier's forms, adapting them in order to connect with the emerging spirit of collective welfare, announcing the upcoming establishment of Swedish Social-Democracy. 'Architecture or revolution', the title of the final chapter in Le Corbusier's Vers une architecture (1923) presents architecture as a tool for the regeneration of "an organic social hole" avoiding revolution, in the words of Helena Mattsson and Sven-Olov Wallenstein. This proposition found some similarities in the Swedish debate around the 1920s, when "home' was seen as a salvation from an impending Bolshevik revolution and the dwelling became the place where a concrete politicizing of architecture must take place" 24 . Elin Wägner, an influential political writer of the time, pointed out that the upcoming exhibition was a "revolution from below", a transformative force of the production processes and the way of living. ${ }^{25}$

\section{The mid-1930s to the 1950s. Urban planning in Stockholm and suburbs. Le Corbusier's point blocks as a model and a point of departure}

After 1930, urban planners in Sweden began experimenting with housing, bearing in mind Le Corbusier's principles. During the interwar period, Swedish living conditions were poor, to the point of being considered among the worst housing standards in 1930's Europe. ${ }^{26}$ At that time, the recently elected Social Democratic government focused on housing issues. The new policies in urban planning ran parallel to changes in the social sphere demanding greater equality. "Because of the success of the housing programme and the comparative lack of public opposition to the new architecture," in the words of Alan Colquhoun "the Modern Movement in Sweden was completely lacking in the Jacobinism of the French and German movements"27.

In central Stockholm, the urban planner Albert Lilienberg devised a competition in 1932 for the extension of the major Sveavägen Road down to Gustav Adolfs Torg Square, located in Nedre Norrmalm district. However, the municipal administration eventually refocused this competition on whether to extend this road or not. ${ }^{28}$ The competition committee, which included architects, politicians and foreign experts, observed that the existing street grids and buildings in the neighbourhood were not suitable for the effective functioning of the city and that

\footnotetext{
${ }^{22}$ López-Peláez, José Manuel: “Asplund’s Maturity”. En López-Peláez, José Manuel; Fernández Elorza, Héctor; Rudberg, Eva (Comp.): Exposición Universal de Estocolmo 1930. Madrid: Editorial Rueda, 2004. p.45.

${ }^{23}$ Frampton, Kenneth: "Stockholm 1930, Asplund and the legacy of funkis". In Caldenby, Claes; Hultin, Olof; Asplund: a book. New York: Ginko Press, 1985. p. 35.

${ }^{24}$ Mattson, Helena; Wallenstein, Sven-Olov: Swedish Modernism: Architecture, Consumption and the Welfare Stat. London: Black Dog Publishing, 2010. p. 17.

${ }^{25}$ Mattson, Helena; Wallenstein, Sven-Olov: Swedish Modernism: Architecture, Consumption and the Welfare Stat. London: Black Dog Publishing, 2010. p. 17.

${ }^{26}$ Nyström, Louise; Lundström, Mats Johan: "Sweden: The Life and Death and Life of Great Neighbourhood Centres”. In Built Environment. 2006, $\mathrm{N}^{\circ}$ 32/1. pp. 34.

${ }^{27}$ Colquhoun, Alan: Modern Architecture. Oxford-New York: Oxford University Press, 2002. p.195.

${ }^{28}$ Hall, Thomas: Stockholm: The making of a Metropolis. New York: Routledge, 2009. p.118.
} 
proposals should aim to give "a clear and logical expression to the role of the district as a commercial centre," encouraging the opening of Gustav Adolf Torg Square northwards. ${ }^{29}$

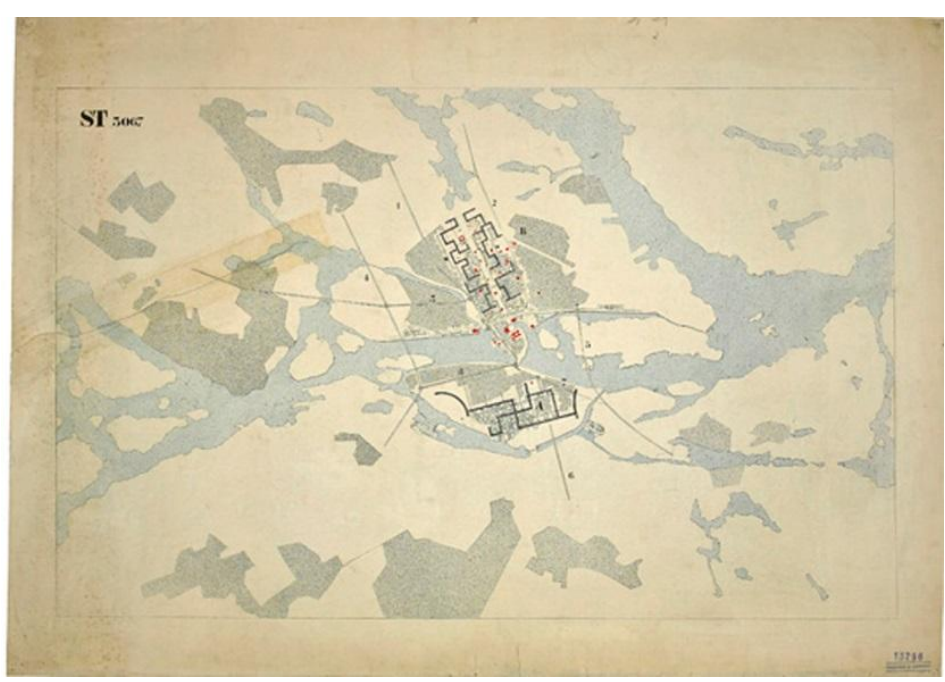

5. Le Corbusier's urban plan of Stockholm for the Nedre Norrmalm competition of 1933.

The competition attracted 350 entries, with many foreign participants. ${ }^{30}$ Alvar Aalto proposed free-standing slab blocks. Le Corbusier's entry replaced older buildings with modern point blocks. In the opinion of Thomas Hall, Le Corbusier's entry was "no doubt intended to provoke debate"31. In fact, Le Corbusier had asked Rudolf Cronstedt, a draughtsman who had worked in his atelier in Rue de Sèvres, to arrange a series of lectures in Stockholm as early as January $1933 .^{32}$

In an article published in 1934, architect and urban planner Sven Markelius considered that the problem with this competition had been that most entries were utopian and out of touch with the reality of things, including Le Corbusier's project. ${ }^{33}$ Le Corbusier's entry was never officially developed, and yet, after a long process culminating in 1957, the urban plan reflects some of his ideas.

Markelius had been Director of Town Planning in Stockholm since 1944 and had directed post-war urban development in the city, after building the Swedish pavilion for the New York Exhibition in 1939. His contributions to the United Nations complex with Le Corbusier and Oscar Niemeyer had brought him international recognition. For Stockholm, Markelius planned to demolish the downtown almost in its entirety and replace older buildings with open public spaces, parks and high-rise towers. The eventual construction of highrise buildings and a large open space in the centre of Stockholm was in many ways similar to Le Corbusier's 1922 project "a contemporary city for three million inhabitants". Le Corbusier had aimed to make space and light available to all within the city centre, to avoid wasting land elsewhere. ${ }^{34}$

\footnotetext{
${ }^{29}$ Hall, Thomas: Stockholm: The making of a Metropolis. New York: Routledge, 2009. p.118.

${ }^{30}$ Hall, Thomas: Stockholm: The making of a Metropolis. New York: Routledge, 2009. p. 118.

${ }^{31}$ Hall, Thomas: Stockholm: The making of a Metropolis. New York: Routledge, 2009. p. 120.

${ }^{32}$ Linton, Johan: Le Corbusier's Plan for the Urbanization of Stockholm. Stockholm: Moderna Museet, 2013. p.2.

${ }^{33}$ Capobianco, Lorenzo: Sven Markelius, Architettura e città. Napoli: Electa Napoli, 2006. p.17.

${ }^{34}$ Curtis, William J R: Le Corbusier, Ideas and Forms. London-New York: Phaidon, 1986 (2015). p. 110.
} 


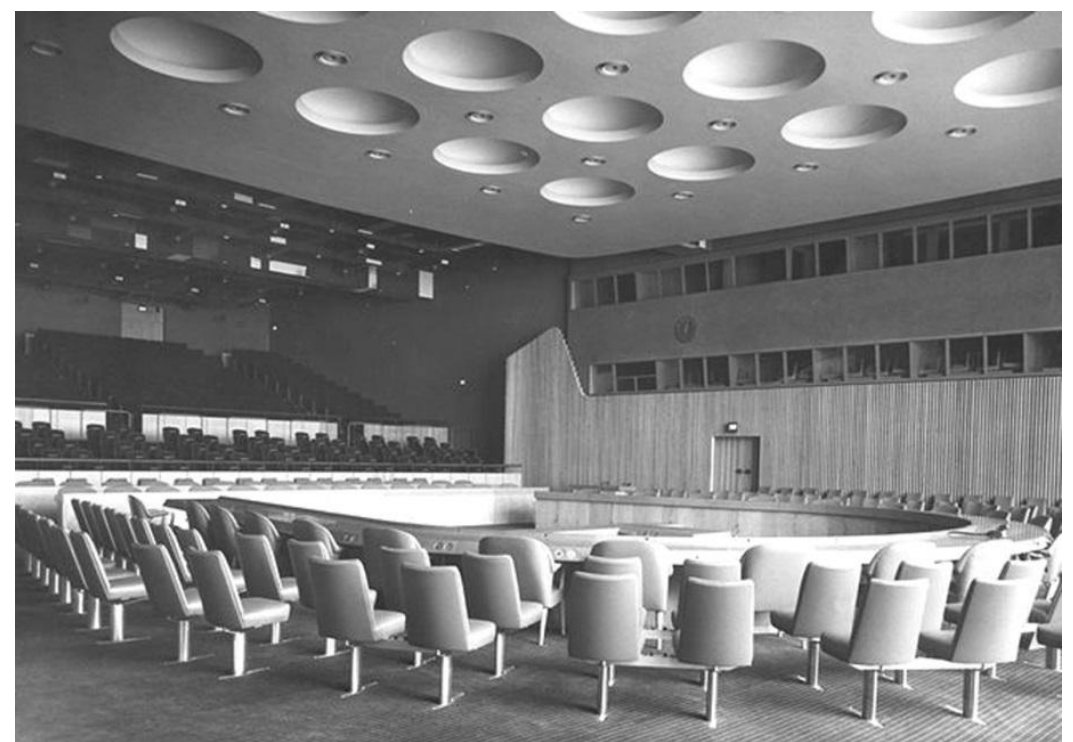

6. Sven Markelius' meeting room for United Nations, 1947-52.

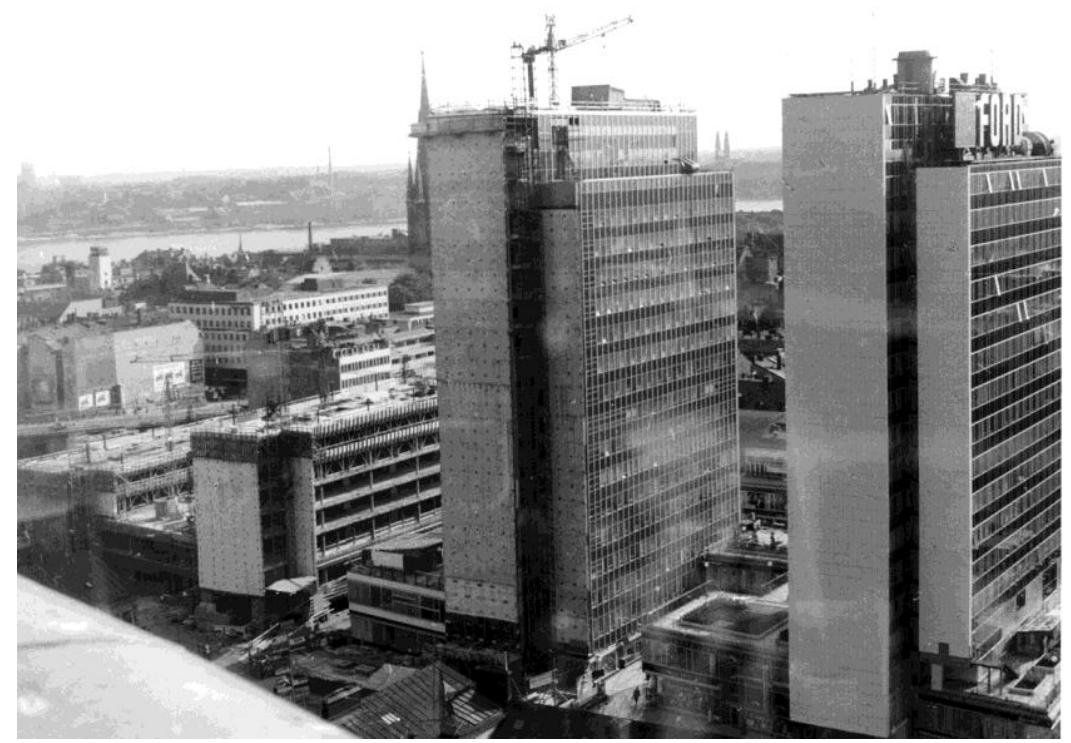

7. Sven Markelius' urban plan of Stockholm devised the demolition of the pre-existing blocks to build high-rise towers. Hötorgscity and Sergels Torg, 1952-1956.

Stockholm's modernisation project triggered numerous demolitions in Stockholm's city centre, most of the Renaissance blocks being replaced, as well as part of the surrounding eighteenth- and nineteenth-century buildings, ${ }^{35}$ to become, in the words of Swedish architect Thordis Arrhenius, "one of the most ambitious and costly urban projects in postwar Europe" ${ }^{\text {"36 }}$. Former housing was replaced with large-scale city blocks of offices, commercial units and a new cultural complex, Kulturhuset (1971-74) designed by architect Peter Celsing (192074), in a process that was completed in the late 1970s.

\footnotetext{
${ }^{35}$ Arrhenius, Thordis: "Preservation and Protest, Counterculture and Heritage in 1970s Sweden." In Future Anterior. 2010, $\mathrm{N}^{\mathrm{o}} 7 / 2$. pp. 110 .

${ }^{36}$ Arrhenius, Thordis: "Preservation and Protest, Counterculture and Heritage in 1970s Sweden." In Future Anterior. 2010 , $\mathrm{N}^{\mathrm{o}} 7 / 2$. pp.111.
} 
Parallel to these developments, the Social Democratic government appointed a parliamentary commission on housing, which included some of the most progressive architects, such as Uno Åhrén and Sven Wallander, and the economist, sociologist and politician Gunnar Myrdal. ${ }^{37}$ Their 1946 report lay the foundations for a new housing policy and a new Building Act in 1947. Lewis Mumford's book The Culture of Cities, translated into Swedish in 1942, and the Greater London Plan of 1944 were also important influences. The Stockholm Exhibition had been the big break-through for Swedish modernism and over the following years, various suburbs of three-storey, light-coloured apartment buildings were developed. However, some critiques were raised regarding the lack of socially-minded spaces in these new approaches.

Just one year before, Markelius had launched his vision of neighbourhood planning as the new way of developing Stockholm, as published in a booklet co-authored with Göran Sidenbladh. ${ }^{38}$ Markelius and Sidenbladh's plan laid new suburban clusters of about 10,000 inhabitants along the recently established underground system. Each cluster followed the idea of the ABC town: Arbete (work), Bostäder (housing) and Centre (commercial and public services at its centre).

Based on the ABC premises, Markelius planned Vällingby in the suburbs of Stockholm in 1952, thereafter a reference for urban planners worldwide. Vällingby was planned as the largest suburban neighbourhood in Sweden, including a variety of houses and informal groupings. Blocks of flats were built around the centre and single-family houses further away, with the aim of highlighting pedestrian walkways. Vällingby Centre is surrounded by the Greater Vällingby area, which consists of five districts for around 80,000 inhabitants.

Additionally, Vällingby Centre was designed by Leif Reinius (1907-1995) and Sven Backström (1903-1992), who had worked with Le Corbusier between 1932 and 1933. The project became so important that Vällingby Centre was inaugurated in 1954 in the presence of the Royal Family, several members of the Swedish Government and the Parliament, as well as other politicians and decision-makers, and several surrounding housing areas were completed within the following year. Le Corbusier visited Vällingby in 1958.

\footnotetext{
${ }^{37}$ Nyström, Louise; Lundström, Mats Johan: "Sweden: The Life and Death and Life of Great Neighbourhood Centres”. In Built Environment. 2006, № 32/1. pp. 33.

${ }^{38}$ Nyström, Louise; Lundström, Mats Johan: "Sweden: The Life and Death and Life of Great Neighbourhood Centres". In Built Environment. 2006, No 32/1. pp. 34.
} 


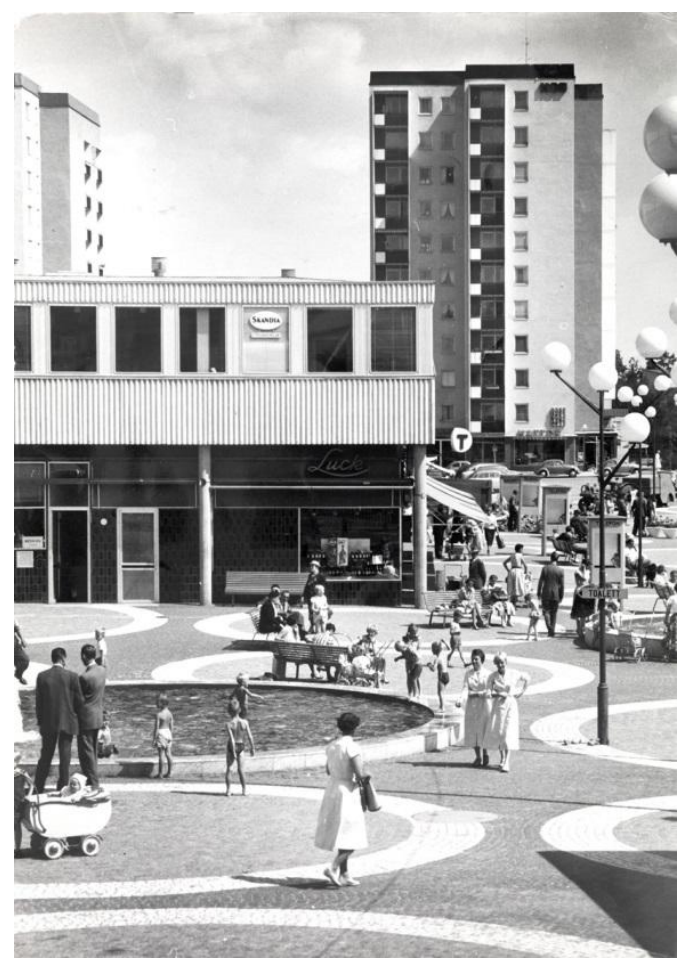

8. Vällingby Centre was designed by Leif Reinius (1907-1995) and Sven Backström (1903-1992)

Vällingby has drawn both strong appraisals and critiques. It became a benchmark for urban planners and the materialisation of many ideas about new towns of that time. It also relied mainly on commercial activity, becoming somewhat unsustainable in social terms. ${ }^{39}$ Vällingby enhanced a close relationship between the individual, everyday life and the landscape.

\section{The 1950s-1970s. Béton brut - Brutalism}

After 1950, many works in Sweden began to emphasise the texture of material, and Le Corbusier's use of concrete became a benchmark. Léonie Geisendorf (1914-), a Swiss architect who had worked for Le Corbusier, designed with her husband St Görans Gymnasium in Stockholm, in the 1950s, and Villa Delin; both works made profuse use of rough concrete. She had helped Le Corbusier with Le Pavilion des Temps Nouveaux for the 1937 Paris Exposition. ${ }^{40}$

\footnotetext{
${ }^{39}$ Ingersoll, Richard: "Second Nature: On the Social Bond of Ecology and Architecture". En Dutton, Thomas; Hurst Mann, Lian (Ed.): Reconstructing Architecture: Critical Discourses and Social Practices. Minneapolis, MN: University of Minnesota Press, 1996. p. 134.

${ }^{40}$ Hallemar, Dan; Lauri, Tomas; Svensson, Julia; Lundqvist, Marianne; Berving, Tobias, Upwind Geisendorf 2014. Stockholm: Arkitektur- och designcentrum, 2014. p. 12.
} 


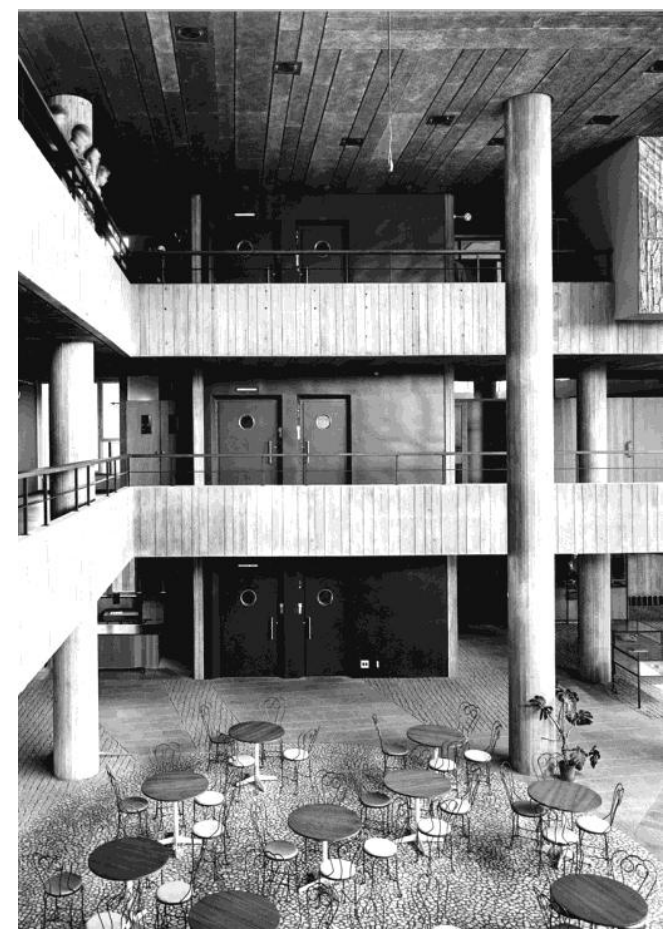

9. St Görans Gymnasium in Stockholm by Léonie and Charles-Edouard Geisendorf, 1956-1973.

A close friend of Geisendorf's, ${ }^{41}$ Ralph Erskine, completed the housing, school and commercial centre in Gyttorp in 1955, both works emphasising the rough texture in the poured concrete. By contrast, Erskine's criticism of modernism aligned with the ideas of Team X, with which he had contacts. ${ }^{42}$ Erskine was particularly receptive to human behaviour and community dynamics. ${ }^{43}$ According to Erskine: "zoning is a misunderstanding of functionalism ${ }^{\text {,44 }}$.

Sigurd Lewerentz, who admired the works of Le Corbusier, designed the churches of Markuskyrkan in 1956 and St Peter's in Klippan in 1966, with a wider international impact. Peter Celsing completed St Thomas' Church in 1959 and most notably, his building of the Filmhuset (completed in 1970) could be regarded as influenced by Le Corbusier's works, such as La Tourette. In his 1966 book The New Brutalism: Ethic or Aesthetic?, Reyner Banham included several works by Le Corbusier, as well as Lewerentz's Markuskyrkan Church.

${ }^{41}$ Hallemar, Dan; Lauri, Tomas; Svensson, Julia; Lundqvist, Marianne; Berving, Tobias, Upwind Geisendorf 2014. Stockholm: Arkitektur- och designcentrum, 2014. p. 15.

42 Caldenby, Claes: “The Time of the Large Programmes 1960-75.” En Cladenby, Claes; Lindvall, Jöran; Wang, Wilfried (Ed.): Sweden 20th Century Architecture. Munich-New York: Prestel, 1998. p.146.

${ }^{43}$ Walters, David; Brown, Linda. Design First. Oxford: Architectural Press, 2004. P. 17.

${ }^{44}$ Caldenby, Claes: "The Time of the Large Programmes 1960-75." En Cladenby, Claes; Lindvall, Jöran; Wang, Wilfried (Ed.): Sweden 20th Century Architecture. Munich-New York: Prestel, 1998. p.146. 


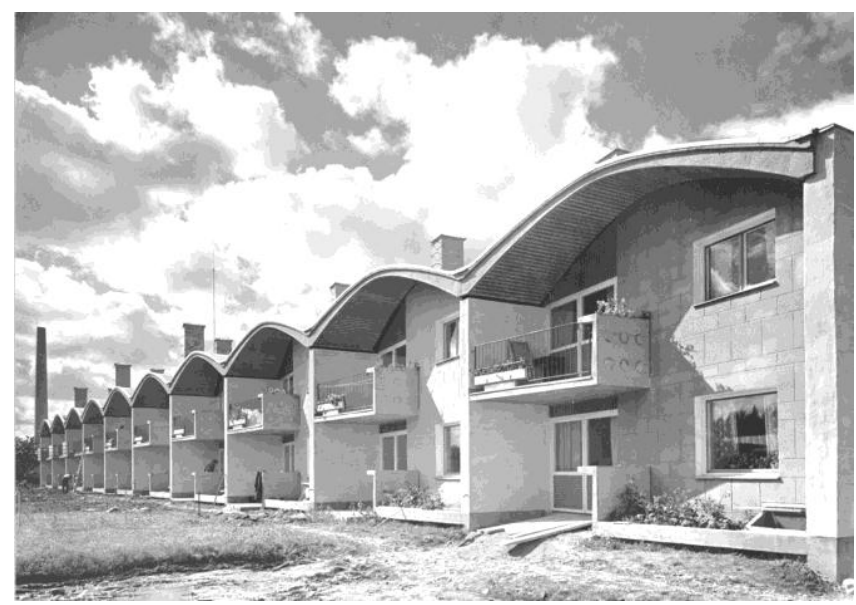

10. Ralph Erskine, row-houses in Gyttorp, 1945-55.

\section{Conclusions}

An analysis of Swedish adaptation and transformation of elements from Le Corbusier's projects shows how Swedish architects developed innovative designs by exploring new applications of Le Corbusier's forms and materials. They transformed his approaches into alternative uses, adapting them to place and the social conditions specific to Scandinavia.

Some of Le Corbusier's construction methods served to materialise ideas that, in principle, seemed very different, if not opposing, such as Åhrén and Erskine's. These subversive results reflect not only the complexity of Le Corbusier's legacy, but also the adaptation of new, similar forms for different identities. Swedish adaptation of Le Corbusier's elements became a resource for producing novel designs, which in turn impacted on the international arena.

\section{Acknowledgements}

I am grateful to the Swedish Design Centre for Architecture and Design in Stockholm and Fondation Le Corbusier for their help.

\section{Source of images}

Figure 1. Photograph by the Author.

Figure 2. The Swedish Centre for Architecture and Design. Photographer unknown.

Figure 3. The Swedish Centre for Architecture and Design. Photographer Gustaf W:son Cronquist.

Figure 4. The Swedish Centre for Architecture and Design. Photographer C. G. Rosenberg.

Figure 5. Le Corbusier/BUS 2012.

Figure 6. The Swedish Centre for Architecture and Design. Photographer unknown.

Figure 7. The Swedish Centre for Architecture and Design. Photographer unknown.

Figure 8. The Swedish Centre for Architecture and Design. Lennart Olson.

Figure 9. The Swedish Centre for Architecture and Design. Photographer Sune Sundahl.

Figure 10. The Swedish Centre for Architecture and Design. Photographer Sune Sundahl. 


\section{References}

Arrhenius, Thordis: "Preservation and Protest, Counterculture and Heritage in 1970s Sweden." In Future Anterior. 2010, No 7/2. pp. 106-123.

Brandão Jönsson, Henrik. Fantasiön: ett reportage från Brasiliens hjärta. Stockholm: Atlas, 2010.

Caldenby, Claes: “The Time of the Large Programmes 1960-75.” En Cladenby, Claes; Lindvall, Jöran; Wang, Wilfried (Ed.): Sweden 20th Century Architecture. Munich-New York: Prestel, 1998.

Capobianco, Lorenzo: Sven Markelius, Architettura e città. Napoli: Electa Napoli, 2006.

Cohen, Jean-Louis: Le Corbusier, 1887-1965. Köln: Taschen, 2004.

Colquhoun, Alan: Modern Architecture. Oxford-New York: Oxford University Press, 2002.

Creagh, Lucy: “An Introduction to acceptera”. En Creagh, Lucy; Kåberg, Helena; Miller Lane, Barbara (Ed.): Modern Swedish Design. New York: The Museum of Modern Art, 2008.

Curtis, William J R: Le Corbusier, Ideas and Forms. London-New York: Phaidon, 1986 (2015).

Eriksson, Eva: "Rationalism and Classicism 1915-30.” In Cladenby, Claes; Lindvall, Jöran; Wang, Wilfried (Ed.): Sweden 20th Century Architecture. Munich-New York: Prestel, 1998.

Frampton, Kenneth: "Stockholm 1930, Asplund and the legacy of funkis". In Caldenby, Claes; Hultin, Olof; Asplund: a book. New York: Ginko Press, 1985. pp. 35-39.

Gasterland-Gustafsson, Grechen: Design for Living: German and Swedish Design in the Early Twentieth Century. Doctoral Thesis. Supervisor: Jochen Schulte-Sasse. University of Minnesota, 2008.

Hall, Thomas: Stockholm: The making of a Metropolis. New York: Routledge, 2009.

Hallemar, Dan; Lauri, Tomas; Svensson, Julia; Lundqvist, Marianne; Berving, Tobias, Upwind Geisendorf 2014. Stockholm: Arkitektur- och designcentrum, 2014.

Ingersoll, Richard: "Second Nature: On the Social Bond of Ecology and Architecture". En Dutton, Thomas; Hurst Mann, Lian (Ed.): Reconstructing Architecture: Critical Discourses and Social Practices. Minneapolis, MN: University of Minnesota Press, 1996.

Kåberg, Helena: “An Introduction to Gregor Paulsson's Better Things for Everyday Life.” In Creagh, Lucy; Kåberg, Helena; Miller Lane, Barbara (Ed.): Modern Swedish Design. New York: The Museum of Modern Art, 2008.

Linton, Johan: Le Corbusier's Plan for the Urbanization of Stockholm. Stockholm: Moderna Museet, 2013.

López-Peláez, José Manuel: “Asplund’s Maturity”. En López-Peláez, José Manuel; Fernández Elorza, Héctor; Rudberg, Eva (Comp.): Exposición Universal de Estocolmo 1930. Madrid: Editorial Rueda, 2004. pp. 41-51.

Mattson, Helena; Wallenstein, Sven-Olov: Swedish Modernism: Architecture, Consumption and the Welfare State. London: Black Dog Publishing, 2010.

Nyström, Louise; Lundström, Mats Johan: "Sweden: The Life and Death and Life of Great Neighbourhood Centres”. In Built Environment. 2006, No 32/1. pp. 32-52.

Rudberg, Eva: “Early Functionalism 1930-40.” En Cladenby, Claes; Lindvall, Jöran; Wang, Wilfried (Ed.): Sweden 20th Century Architecture. Munich-New York: Prestel, 1998.

Rudberg, Eva: “The Stockholm Exhibition 1930”. In López-Peláez, José Manuel; Fernández Elorza, Héctor; Rudberg, Eva (Comp.): Exposición Universal de Estocolmo 1930. Madrid: Editorial Rueda, 2004. pp. 25-39.

Walters, David; Brown, Linda. Design First. Oxford: Architectural Press, 2004. 